\title{
Hyperthyroidism and Renal Disorders
}

\author{
Ahmed R.G \\ Division of Anatomy and Embryology, Zoology Department, Faculty of Science, Beni-Suef University, Beni- \\ Suef, Egypt
}

*Corresponding Author: Ahmed R.G, Division of Anatomy and Embryology, Zoology Department, Faculty of Science, Beni-Suef University, Beni-Suef, Egypt. Email: ahmedragab08@gmail.com

\section{COMMENTARY}

The normal levels of thyroid hormones (THs) during the gestation (El-bakry et al., 2010; Ahmed, 2011, 2012a,b, 2013, 2014, 2015a-c, 2016a-d, 2017a-v \& 2018a-s; Ahmed et al., 2008, 2010, 2012, 2013a,b, 2014; 2015a,b\& 2018a,b; Ahmed and Ahmed, 2012; Ahmed and Incerpi, 2013; Van Hercket al., 2013; Ahmed and El-Gareib, 2014,Incerpi et al., 2014; Candelotti et al., 2015; De Vito et al., 2015; ElGhareeb et al., 2016; Ahmed and El-Gareib, 2017; Endendijk et al., 2017; Gigena et al., 2017) are crucial for the renal homeostasis and development(Iglesias and Diez, 2009; Mariani and Berns, 2012; Dousdampanis et al., 2014; Iglesias et al., 2016).As well, THs adjust the transportation during the proximal convoluted tubule (Basu and Mohapatra, 2012).

Hyperthyroidism can alter the hemodynamic processessuch as increase the sensitivity to $\beta$ adrenergic stimulus, the release of renin, the angiogenesis, the nitric oxide (NO) levels and the filtration pressure (Danzi and Klein, 2003; Fazio et al., 2004; Iglesias et al., 2005; Kahaly and Dillmann, 2005; Prisant et al., 2006; Vargas et al., 2012; Rodriguez-Gomez et al., 2013; Koch and Chrousos, 2016). In addition, Hyperthyroidism can alter the glomerular processes (Conger et al., 1989; Graves et al., 1994; den Hollander et al., 2005; Vargas et al., 2006; Syme, 2007; Iglesias et al., 2016) as the following: (1) increases the glomerular filtration rate (GFR) and the levels of cystatin C; (2) accelerates the chronic kidney disease (CKD); (3) Intraglomerular hypertension and hyperfiltration; and (4) decreases the serum creatinine level. On the other hand,
Hyperthyroidism can vary the tubular processes (Wijkhuisen et al., 1995; Baum et al., 1998; Kumar and Prasad, 2002; Wang et al., 2007; Pothiwala and Levine, 2010) as the following: (1) decreases the ability to concentrate urine;(2) increases the activity of $\mathrm{Na}-\mathrm{H}$ exchanger and $\mathrm{Na}+\mathrm{K}+-\mathrm{ATPase} ;(3)$ elevates the reabsorption capacity and tubular secretory;(4) increases the calcium reabsorption; and (5) elevates the reabsorption of sodium and chloride. As well, in hyperthyroid rats, the elevation in the renal and cardiac capillarity and in the vascularization of the mesenteric bed was observed by RodriguezGomez et al. (2013) and Iglesias et al. (2016). On the other hand, the hyper-functioning of thyroid gland can (1) decrease the vascular resistance by increasing the vasodilation and reducing the vasoconstriction(Fazio et al., 2004; Kahaly and Dillmann, 2005; Iglesias et al., 2016); (2) increase the systolic blood pressure by decreasing the systemic vascular resistance, and elevating the heart rate and cardiac output (Woeber, 1992; Danzi and Klein, 2003; Iglesias et al., 2005; Prisant et al., 2006; Koch and Chrousos, 2016); and (3) increase the level of NO causing a hyperdynamic circulation (Iglesias et al., 2016). However, standardization the function of thyroid by therapy of thyrotoxicosis might normalize the renal function (den Hollander et al., 2005). On the basis of these data, it can be inferred that the thyroid dysfunction (hyperthyroidism) may disturb the renal development and function. Further investigations are desired to understand the probable connections between the thyroid disorders (hyperthyroidism) and kidney during the gestation and lactation to avoid unnecessary treatments. 


\section{REFERENCES}

[1] Ahmed, O.M., Abd El-Tawab, S.M., Ahmed, R.G., 2010. Effects of experimentally induced maternal hypothyroidism and hyperthyroidism on the development of rat offspring: I- The development of the thyroid hormonesneurotransmitters and adenosinergic system interactions. Int. J. Dev. Neurosci. 28, 437-454.

[2] Ahmed, O.M., Ahmed, R.G., 2012. Hypothyroidism. In A New Look At Hypothyroidism. Dr. D. Springer (Ed.), ISBN: 978-953-51-0020-1), In Tech Open Access Publisher, Chapter 1, pp. 1-20.

[3] Ahmed, O.M., Ahmed, R.G., El-Gareib, A.W., El-Bakry, A.M., Abd El-Tawaba, S.M., 2012. Effects of experimentally induced maternal hypothyroidism and hyperthyroidism on the development of rat offspring: II-The developmental pattern of neurons in relation to oxidative stress and antioxidant defense system. Int. J. Dev. Neurosci. 30, 517-537.

[4] Ahmed, O.M., El-Gareib, A.W., El-bakry, A.M., Abd El-Tawab, S.M., Ahmed, R.G., 2008. Thyroid hormones states and brain development interactions. Int. J. Dev. Neurosci. 26(2), 147-209. Review.

[5] Ahmed, R.G., 2011. Perinatal 2, 3, 7, 8tetrachlorodibenzo-p-dioxin exposure alters developmental neuroendocrine system. Food Chem. Toxicology, 49, 1276-1284.

[6] Ahmed, R.G., 2012a. Maternal-newborn thyroid dysfunction. In the Developmental Neuroendocrinology, pp. 1-369. Ed R.G. Ahmed. Germany: LAP LAMBERT Academic Publishing GmbH \& Co KG.

[7] Ahmed, R.G., 2012b. Maternal-fetal thyroid interactions, Thyroid Hormone, Dr. N.K. Agrawal (Ed.), ISBN: 978-953-51-0678-4, In Tech Open Access Publisher, Chapter 5, pp. 125-156.

[8] Ahmed, R.G., 2013. Early weaning PCB 95 exposure alters the neonatal endocrine system: thyroid adipokine dysfunction. J. Endocrinol. 219 (3), 205-215.

[9] Ahmed, R.G., 2014. Editorial: Do PCBs modify the thyroid-adipokine axis during development? Annals Thyroid Res. 1(1), 11-12.

[10] Ahmed, R.G., 2015a. Chapter 1: Hypothyroidism and brain development. In advances in hypothyroidism treatment. Avid Science Borsigstr.9, 10115 Berlin, Berlin, Germany. Avid Science Publications level 6, Melange Towers, Wing a, Hitec City, Hyderabad, Telangana, India. pp. 1-40.

[11] Ahmed, R.G., 2015b. Hypothyroidism and brain developmental players. Thyroid Research J. 8(2), 1-12.

[12] Ahmed, R.G., 2015c. Editorials and Commentary: Maternofetal thyroid action and brain development. J. of Advances in Biology; 7(1), 1207-1213.

[13] Ahmed, R.G., 2015d. Developmental a dipokines and maternal obesity interactions. J. of Advances in Biology; 7(1), 1189-1206.

[14] Ahmed, R.G., 2016a. Maternal bisphenol A alters fetal endocrine system: Thyroid adipokine dysfunction. Food Chem. Toxicology, 95, 168-174.

[15] Ahmed, R.G., 2016b. Gestational dexamethas one alters fetal neuroendocrine axis. Toxicology Letters, 258, 46-54.

[16] Ahmed, R.G., 2016c. Maternal iodine deficiency and brain disorders. Endocrinol. Metab.Syndr.5, 223. http://dx.doi.org/ 10.4172/ 2161-1017.1000223.

[17] Ahmed, R.G., 2016d. Neonatal polychlorinated biphenyls-induced endocrine dysfunction. Ann. Thyroid. Res. 2 (1), 34-35.

[18] Ahmed, R.G.,2017a. Developmental thyroid diseases and GABAergic dysfunction. EC Neurology 8.1, 02-04.

[19] Ahmed, R.G., 2017b. Hyperthyroidism and developmental dysfunction. Arch Med. 9, 4.

[20] Ahmed, R.G.,2017c. Anti-thyroid drugs may be at higher risk for perinatal thyroid disease. EC Pharmacology and Toxicology 4.4, 140-142.

[21] Ahmed, R.G.,2017d. Perinatal hypothyroidism and cytoskeleton dysfunction. Endocrinol MetabSyndr 6, 271.doi:10.4172/2161-1017. 1000271

[22] Ahmed, R.G.,2017e. Developmental thyroid diseases and monoaminergic dysfunction. Advances in Applied Science Research 8(3), 01-10.

[23] Ahmed, R.G.,2017f. Hypothyroidism and brain development.J. Anim Res Nutr.2(2), 13.

[24] Ahmed, R.G.,2017g. Antiepileptic drugs and developmental neuroendocrine dysfunction: Every why has A Wherefore.Arch Med 9(6), 2.

[25] Ahmed, R.G.,2017h. Gestational prooxidantantioxidant imbalance may be at higher risk for postpartum thyroid disease. Endocrinol MetabSyndr 6, 279. doi:10.4172/21611017.1000279.

[26] Ahmed, R.G.,2017i. Synergistic actions of thyroid-adipokines axis during development. EndocrinolMetabSyndr 6, 280.doi:10.4172/ 2161-1017. 1000280.

[27] Ahmed, R.G.,2017j. Thyroid-insulin dysfunction during development. International Journal of Research Studies in Zoology 3(4), 73-75. DOI: http://dx.doi.org/10.20431/2454941X.0304010.

[28] Ahmed, R.G.,2017k. Developmental thyroid diseases and cholinergic imbalance. 
International Journal of Research Studies in Zoology 3(4), 70-72. DOI: http://dx.doi.org/ 10.20431/2454-941X.0304009.

[29] Ahmed, R.G.,20171. Thyroid diseases and developmental adenosinergic imbalance. Int $\mathrm{J}$ ClinEndocrinol 1(2), 053-055.

[30] Ahmed, R.G.,2017m. Maternal anticancer drugs and fetal neuroendocrine dysfunction in experimental animals. EndocrinolMetabSyndr 6, 281.doi:10.4172/2161-1017.1000281.

[31] Ahmed, R.G.,2017n. Letter: Gestational dexamethasone may be at higher risk for thyroid disease developing peripartum. Open Journal Of Biomedical \& Life Sciences (Ojbili) 3(2), 01-06.

[32] Ahmed, R.G.,2017o. Deiodinases and developmental hypothyroidism. EC Nutrition $11.5,183-185$.

[33] Ahmed, R.G.,2017p. Maternofetal thyroid hormones and risk of diabetes. Int. J. of Res. Studies in Medical and Health Sciences 2(10), 18-21.

[34] Ahmed, R.G.,2017r. Association between hypothyroidism and renal dysfunctions. International Journal of Research Studies in Medical and Health Sciences 2(11), 1-4.

[35] Ahmed, R.G.,2017s. Maternal hypothyroidism and lung dysfunction. International Journal of Research Studies in Medical and Health Sciences 2(11), 8-11.

[36] Ahmed, R.G.,2017t. Endocrine disruptors; possible mechanisms for inducing developmental disorders. International journal of basic science in medicine (IJBSM)2(4), 157160.

[37] Ahmed, R.G.,2017u. Maternal thyroid hormones trajectories and neonatal behavioral disorders. ARC Journal of Diabetes and Endocrinology 3(2), 18-21.

[38] Ahmed, R.G.,2017v. Maternal thyroid dysfunction and neonatal cardiac disorders. Insights Biol Med. 1, 092-096.

[39] Ahmed, R.G.,2018a. Maternal hypothyroidism and neonatal testicular dysfunction. International Journal of Research Studies in Medical and Health Sciences 3(1), 8-12.

[40] Ahmed, R.G.,2018b. Maternal hypothyroidism and neonatal depression: Current perspective. International Journal of Research Studies in Zoology 4(1), 6-10. DOI: http://dx.doi.org/ 10.20431/2454-941X.0401002.

[41] Ahmed, R.G.,2018c. Non-genomic actions of thyroid hormones during development. App ClinPharmacolToxicol: ACPT-108. DOI: 10.29011/ACPT-109. 100008.

[42] Ahmed, R.G.,2018d. Maternal thyroid function and placental hemodynamics. ARC Journal of Animal and Veterinary Sciences 4(1), 9-13.
DOI: $\quad$ http://dx.doi.org/10.20431/2455-2518. 0401002.

[43] Ahmed, R.G.,2018e. Interactions between thyroid and growth factors during development. ARC Journal of Diabetes and Endocrinology 4(1), 1-4. DOI: http://dx.doi.org/ 10.20431/ 2455-5983.0401001.

[44] Ahmed, R.G.,2018f. Maternal thyroid hormones and neonatal appetite. ARC Journal of Nutrition and Growth 4(1), 18-22. DOI: http://dx.doi.org/ 10.20431/2455-2550. 040100 5.

[45] Ahmed, R.G.,2018g. Genomic actions of thyroid hormones during development. ARC Journal of Diabetes and Endocrinology 4(1), 58. DOI: http://dx.doi.org/10.20431/2455-5983. 0401002.

[46] Ahmed, R.G.,2018h. Dysfunction of maternal thyroid hormones and psychiatric symptoms. American Research Journal of Endocrinology. 2(1), 1-6.

[47] Ahmed, R.G.,2018i. Is there a connection between maternal hypothyroidism and developing autism spectrum disorders? ARC Journal of Neuroscience 3(1), 5-8. DOI: http://dx.doi.org/10.20431/2456-057X. 03010 02 .

[48] Ahmed, R.G.,2018j.Maternal thyroid dysfunctions and neonatal bone mal development.American Research Journal of Endocrinology (in press) $\mathrm{xx}$-Xxx.

[49] Ahmed, R.G., 2018k. Maternal thyroid disorders and risk of neonatal seizure: Current perspective. ARC Journal of Neuroscience 3(1), 21-25. DOI: http://dx.doi.org/10.20431/2456057X.0301004

[50] Ahmed, R.G., 20181. Gestational dioxin acts as developing neuroendocrine-disruptor. EC Pharmacology and Toxicology 6.3, 96-100.

[51] Ahmed, R.G.,2018m. Maternal thyroid dysfunction and risk of neonatal stroke. ARC Journal of Animal and Veterinary Sciences 4(1), 22-26. DOI: http://dx.doi.org/ 10.20431 /2455-2518.0401004

[52] Ahmed, R.G.,2018n. Maternal thyroid disorders and developing skin dysfunctions. ARC Journal of Dermatology 3(1), 13-17. DOI: http://dx.doi.org/10.20431/2456-0022.0301005

[53] Ahmed, R.G.,2018o. Maternal hypothyroidismmilk ejections: What is the link? ARC Journal of Nutrition and Growth 4(1), 29-33. DOI: http://dx.doi.org/10.20431/2455-2550.0401007

[54] Ahmed, R.G.,2018p. Does maternal antepartum hypothyroidism cause fetal and neonatal hyponatremia? ARC Journal of Diabetes and Endocrinology 4(1), XX-XXx. DOI: http://dx.doi.org/10.20431/2455-5983.0401004

[55] Ahmed, R.G.,2018q. Maternal hypothyroidism and rheumatoid arthritis. International Journal 
of Research Studies in Medical and Health Sciences Volume 3(2), 1-5.

[56] Ahmed, R.G.,2018r. Developmental thyroid and skeletal muscle dysfunction.ARC Journal of Diabetes and Endocrinology 4(1), xx-xxx. DOI: http://dx.doi.org/10.20431/2455-5983. 04 01003

[57] Ahmed, R.G.,2018s. Maternal thyroid hormones and ageing process. International Journal of Research Studies in Biosciences (IJRSB) 6(2), 30-34. DOI: http://dx.doi.org/ 10.20431/2349-0365.0602005

[58] Ahmed, R.G., Abdel-Latif, M., Ahmed F., 2015b.Protective effects of GM-CSF in experimental neonatal hypothyroidism. International Immuno pharmacology 29, 538543.

[59] Ahmed, R.G., Abdel-Latif, M., Mahdi, E., ElNesr, K., 2015a. Immune stimulation improves endocrine and neural fetal outcomes in a model of maternofetal thyrotoxicosis. Int. Immunopharmacol. 29, 714-721.

[60] Ahmed, R.G., Davis, P.J., Davis, F.B., De Vito, P., Farias, R.N., Luly, P., Pedersen, J.Z., Incerpi, S., 2013b. Nongenomic actions of thyroid hormones: from basic research to clinical applications. An update. Immunology, Endocrine \& Metabolic Agents in Medicinal Chemistry, 13(1), 46-59.

[61] Ahmed, R.G., El-Gareib, A.W. 2014.Lactating PTU exposure: I- Alters thyroid-neural axis in neonatal cerebellum. Eur. J. of Biol. and Medical Sci. Res. 2(1), 1-16.

[62] Ahmed, R.G., El-Gareib, A.W., 2017.Maternal carbamazepine alters fetal neuroendocrinecytokines axis. Toxicology 382, 59-66.

[63] Ahmed, R.G., El-Gareib, A.W., Incerpi, S., 2014. Lactating PTU exposure: II- Alters thyroid-axis and prooxidant-antioxidant balance in neonatal cerebellum. Int. Res. J. of Natural Sciences 2(1), 1-20.

[64] Ahmed, R.G., Incerpi, S., 2013. Gestational doxorubicin alters fetal thyroid-brain axis. Int. J. Devl. Neuroscience 31, 96-104.

[65] Ahmed, R.G., Incerpi, S., Ahmed, F., Gaber, A., 2013a. The developmental and physiological interactions between free radicals and antioxidant: Effect of environmental pollutants. J. of Natural Sci. Res. 3(13), 74-110.

[66] Ahmed, R.G.,El-Gareib, A.W., Shaker, H.M., 2018a.Gestational 3,3',4,4',5-pentachloro biphenyl (PCB 126) exposure disrupts fetoplacental unit: Fetal thyroid-cytokines dysfunction. Life Sciences 192, 213-220.

[67] Ahmed, R.G.,Walaa G.H., Asmaa F.S., 2018b.Suppressive effects of neonatal bisphenol A on the neuroendocrine
system.Toxicology and Industrial Health Journal (in press).

[68] Basu, G., Mohapatra, A., 2012. Interactions between thyroid disorders and kidney disease. Indian J EndocrinolMetab. 2, 204-213.

[69] Baum, M., Dwarakanath, V., Alpern, R.J., Moe, O.W., 1998.Effects of thyroid hormone on the neonatal renal cortical $\mathrm{Na}+\mathrm{H}+$ antiporter. Kidney Int. 5, 1254-1258.

[70] Candelotti, E., De Vito, P., Ahmed, R.G., Luly, P., Davis, P.J., Pedersen, J.Z., Lin, H-Y., Incerpi, I., 2015. Thyroid hormones crosstalk with growth factors: Old facts and new hypotheses. Immun., Endoc.\&Metab. Agents in Med. Chem., 15, 71-85.

[71] Conger, J.D., Falk, S.A., Gillum, D.M., 1989.The protective mechanism of thyroidectomy in a rat model of chronic renal failure.Am J Kidney Dis. 3, 217-225.

[72] Danzi, S., Klein, I., 2003. Thyroid hormone and blood pressure regulation. CurrHypertens Rep. 6, 513-20.

[73] De Vito, P., Candelotti, E., Ahmed, R.G., Luly, P., Davis, P.J., Incerpi, S., Pedersen, J.Z., 2015.Role of thyroid hormones in insulin resistance and diabetes.Immun., Endoc.\&Metab. Agents in Med. Chem., 15, 8693.

[74] den Hollander, J.G., Wulkan, R.W., Mantel, M.J., Berghout, A., 2005. Correlation between severity of thyroid dysfunction and renal function. ClinEndocrinol. 4, 423-427.

[75] Dousdampanis, P., Trigka, K., Vagenakis, G.A., Fourtounas, C., 2014. The thyroid and the kidney: a complex interplay in health and disease. Int J Artif Organs. 1, 1-12.

[76] El-bakry, A.M., El-Ghareeb, A.W.,Ahmed, R.G., 2010.Comparative study of the effects of experimentally-induced hypothyroidism and hyperthyroidism in some brain regions in albino rats.Int. J. Dev. Neurosci. 28, 371-389.

[77] El-Ghareeb, A.A., El-Bakry, A.M., Ahmed, R.G., Gaber, A., 2016.Effects of zinc supplementation in neonatal hypothyroidism and cerebellar distortion induced by maternal carbimazole. Asian Journal of Applied Sciences 4(04), 1030-1040.

[78] Endendijk, J.J., Wijnen, H.A.A., Pop, V.J.M., van Baar, A.L., 2017. Maternal thyroid hormone trajectories during pregnancy and child behavioral problems. Hormones \&Behav. 94, 84-92.

[79] Fazio, S., Palmieri, E.A., Lombardi, G., Biondi, B., 2004.Effects of thyroid hormone on the cardiovascular system. Recent ProgHorm Res. 31-50. 
[80] Gigena, N., Alamino, V.A., Montesinos, M.M., Nazar, M., Louzada, R.A., Wajner, S.M., Maia, A.L., Masini-Repiso, A.M., Carvalho, D.P., Cremaschi G.A., Pellizas, C.G., 2017.Dissecting thyroid hormone transport and metabolism in dendritic cells. J. Endocrinology $232,337-350$.

[81] Graves, T.K., Olivier, N.B., Nachreiner, R.F., Kruger, J.M., Walshaw, R., Stickle, R.L., 1994. Changes in renal function associated with treatment of hyperthyroidism in cats. Am J Vet Res. 12, 1745-1749.

[82] Iglesias, P., Acosta, M., Sanchez, R., Fernandez-Reyes, M.J., Mon, C., Diez, J.J., 2005. Ambulatory blood pressure monitoring in patients with hyperthyroidism before and after control of thyroid function. ClinEndocrinol. 1, 66-72.

[83] Iglesias, P., Bajo, M.A., Selgas, R., Díez, J.J., 2016. Thyroid dysfunction and kidney disease: An update. Rev EndocrMetabDisord DOI 10.1007/s11154-016-9395-7.

[84] Iglesias, P., Diez, J.J., 2009. Thyroid dysfunction and kidney disease.Eur $\mathbf{J}$ Endocrinol. 4, 503-515.

[85] Incerpi, S., Hsieh, M-T., Lin, H-Y., Cheng, GY., De Vito, P., Fiore, A.M., Ahmed, R.G., Salvia, R., Candelotti, E., Leone, S., Luly, P., Pedersen, J.Z., Davis, F.B., Davis, P.J., 2014. Thyroid hormone inhibition in L6 myoblasts of IGF-I-mediated glucose uptake and proliferation: new roles for integrin $\alpha v \beta 3$. Am. J. Physiol. Cell Physiol. 307, C150-C161.

[86] Kahaly, G.J., Dillmann, W.H., 2005. Thyroid hormone action in the heart. Endocr Rev. 5, 704-728.

[87] Kimmel, M., Braun, N., Alscher, M.D., 2012. Influence of thyroid function on different kidney function tests. Kidney Blood Press Res. 1, 9-17.

[88] Koch, C.A., Chrousos, G.P., 2016.Overview of endocrine hypertension. In: Chrousos G, editor. Adrenal disease and function. Endotext [Internet]. Available: http://www.endotext.org/ section/adrenal/.

[89] Kumar, V., Prasad, R., 2002.Molecular basis of renal handling of calcium in response to thyroid hormone status of rat. BiochimBiophysActa. 3, 331-343.
[90] Mariani, L.H., Berns, J.S., 2012. The renal manifestations of thyroid disease. $\mathrm{J}$ Am SocNephrol. 1, 22-26.

[91] Pothiwala, P., Levine, S.N., 2010. Analytic review: thyrotoxic periodic paralysis: a review. J Intensive Care Med. 2, 71-77.

[92] Prisant, L.M., Gujral, J.S., Mulloy, A.L., 2006. Hyperthyroidism: a secondary cause of isolated systolic hypertension. J ClinHypertens (Greenwich) 8, 596-599.

[93] Rodriguez-Gomez, I., Banegas, I., Wangensteen, R., Quesada, A., Jimenez, R., Gomez-Morales, M., et al., 2013. Influence of thyroid state on cardiac and renal capillary density and glomerular morphology in rats. $\mathbf{J}$ Endocrinol. 1, 43-51.

[94] Syme, H.M., 2007. Cardiovascular and renal manifestations of hyperthyroidism. Vet Clin North AmSmallAnimPract. 4, 723-743.

[95] Van Herck, S.L.J., Geysens, S., Bald, E., Chwatko, G., Delezie, E., Dianati, E., Ahmed, R.G., Darras, V.M., 2013.Maternal transfer of methimazole and effects on thyroid hormone availability in embryonic tissues. Endocrinol. 218, 105-115.

[96] Vargas, F., Moreno, J.M., Rodriguez-Gomez, I., Wangensteen, R., Osuna, A., AlvarezGuerra, M., et al., 2006. Vascular and renal function in experimental thyroid disorders. Eur J Endocrinol. 2, 197-212.

[97] Vargas, F., Rodriguez-Gomez, I., VargasTendero, P., Jimenez, E., Montiel, M., 2012.The renin-angiotensin system in thyroid disorders and its role in cardiovascular and renal manifestations.J Endocrinol. 1, 25-36.

[98] Wang, W., Li, C., Summer, S.N., Falk, S., Schrier, R.W., 2007. Polyuria of thyrotoxicosis: down regulation of aquaporin water channels and increased solute excretion. Kidney Int. 9, 1088-1094.

[99] Wijkhuisen, A., Djouadi, F., Vilar, J., MerletBenichou, C., Bastin, J., 1995. Thyroid hormones regulate development of energy metabolism enzymes in rat proximal convoluted tubule. Am J Physiol. 4(Pt 2), F634642.

[100]Woeber, K.A., 1992. Thyrotoxicosis and the heart. N Engl J Med. 2, 94-98.

Citation: Ahmed R.G. Hyperthyroidism and Renal Disorders. ARC Journal of Animal and Veterinary Sciences. 2018; 4(2):1-5. doi: dx.doi.org/ 10.20431/2455-2518.0402001.

Copyright: () 2018 Authors. This is an open-access article distributed under the terms of the Creative Commons Attribution License, which permits unrestricted use, distribution, and reproduction in any medium, provided the original author and source are credited. 